\title{
EPOCA/EUR-OCEANS data compilation on the biological and biogeochemical responses to ocean acidification
}

\author{
A.-M. Nisumaa ${ }^{1,2}$, S. Pesant ${ }^{3}$, R. G. J. Bellerby ${ }^{4,5}$, B. Delille ${ }^{6}$, J. J. Middelburg ${ }^{7,8}$, J. C. Orr ${ }^{9}$, \\ U. RiebeselI ${ }^{10}$, T. Tyrrell ${ }^{11}$, D. Wolf-Gladrow ${ }^{12}$, and J.-P. Gattuso ${ }^{1,2}$ \\ ${ }^{1}$ CNRS-INSU, Laboratoire d'Océanographie de Villefranche (UMR 7093), B.P. 28, \\ 06234 Villefranche-sur-Mer Cedex, France \\ ${ }^{2}$ Université Pierre et Marie Curie-Paris 6, Observatoire Océanologique de Villefranche, \\ 06230 Villefranche-sur-Mer, France \\ ${ }^{3}$ MARUM, Center for Marine Environmental Sciences, Leobener Strasse, 28359, Bremen, Germany \\ ${ }^{4}$ Bjerknes Centre for Climate Research, University of Bergen, Bergen, Allégaten 55, 5007 Bergen, Norway \\ ${ }^{5}$ Geophysical Institute, University of Bergen, Bergen, Allégaten 70, 5007 Bergen, Norway \\ ${ }^{6}$ Unité d'Océanographie Chimique, Université de Liège, 4000 Liège, Belgium \\ ${ }^{7}$ Netherlands Institute of Ecology, Centre for Estuarine and Marine Ecology, Korringaweg 7, P.O. Box 140, \\ 4400 AC Yerseke, The Netherlands \\ ${ }^{8}$ Faculty of Geosciences, Utrecht University, P.O. Box 80021, 3508 TA Utrecht, The Netherlands \\ ${ }^{9}$ LSCE/IPSL, Laboratoire des Sciences du Climat et de l'Environnement, CEA/CNRS/UVSQ, \\ Orme des Merisiers, Bat. 712, 91191 Gif-sur-Yvette cedex, France \\ ${ }^{10}$ Leibniz Institute of Marine Sciences, IFM-GEOMAR, Düsternbrooker Weg 20, 24105 Kiel, Germany \\ ${ }^{11}$ School of Ocean and Earth Science, University of Southampton, National Oceanography Centre \\ Southampton, European Way, Southampton, Hants, SO14 3ZH, UK \\ ${ }^{12}$ AWI for Marine and Polar Research, Am Handelshafen 12, 27570 Bremerhaven, Germany
}

Received: 17 March 2010 - Published in Earth Syst. Sci. Data Discuss.: 30 March 2010 Revised: 2 July 2010 - Accepted: 2 July 2010 - Published: 8 July 2010

\begin{abstract}
The uptake of anthropogenic $\mathrm{CO}_{2}$ by the oceans has led to a rise in the oceanic partial pressure of $\mathrm{CO}_{2}$, and to a decrease in $\mathrm{pH}$ and carbonate ion concentration. This modification of the marine carbonate system is referred to as ocean acidification. Numerous papers report the effects of ocean acidification on marine organisms and communities but few have provided details concerning full carbonate chemistry and complementary observations. Additionally, carbonate system variables are often reported in different units, calculated using different sets of dissociation constants and on different $\mathrm{pH}$ scales. Hence the direct comparison of experimental results has been problematic and often misleading. The need was identified to (1) gather data on carbonate chemistry, biological and biogeochemical properties, and other ancillary data from published experimental data, (2) transform the information into common framework, and (3) make data freely available. The present paper is the outcome of an effort to integrate ocean carbonate chemistry data from the literature which has been supported by the European Network of Excellence for Ocean Ecosystems Analysis (EUR-OCEANS) and the European Project on Ocean Acidification (EPOCA). A total of 185 papers were identified, 100 contained enough information to readily compute carbonate chemistry variables, and 81 data sets were archived at PANGAEA - The Publishing Network for Geoscientific \& Environmental Data. This data compilation is regularly updated as an ongoing mission of EPOCA.
\end{abstract}

Data access: http://doi.pangaea.de/10.1594/PANGAEA.735138

Correspondence to: A.-M. Nisumaa

(nisumaa@obs-vlfr.fr) 


\section{Introduction}

In 2008 fossil fuel use, cement production and changes in land use together have emitted $\sim 8.7 \mathrm{Pg} \mathrm{C}$ to the atmosphere. About half remains in the atmosphere, while the rest is removed in roughly equal parts by ocean and land vegetation (Le Quéré et al., 2009). The world ocean absorbs anthropogenic carbon dioxide $\left(\mathrm{CO}_{2}\right)$ at a rate of approximately 24 million tons per day. The uptake of anthropogenic $\mathrm{CO}_{2}$ by the oceans leads to a rise in the oceanic partial pressure of carbon dioxide $\left(p \mathrm{CO}_{2}\right)$, a decrease in $\mathrm{pH}$, and a reduction in carbonate ion concentration (Orr et al., 2005). These changes result in a drop of calcium carbonate saturation state, making seawater less favourable to precipitation of calcareous shells and skeletons and more favourable to their dissolution (Gattuso et al., 1999). The future rate of change is unprecedented in the past 65 Myr (Ridgwell and Schmidt, 2010). The impacts of ocean acidification on the structure and functioning of marine ecosystems, including their services to our society, is the focus of several international research initiatives such as the European Network of Excellence for Ocean Ecosystems Analysis (EUR-OCEANS), the European Project on OCean Acidification (EPOCA) and a number of national initiatives.

Numerous studies addressed the effects of ocean acidification on organisms and communities (e.g., Gattuso et al., 1999; Riebesell et al., 2000; Delille et al., 2005; Orr et al., 2005), however, the resulting carbonate chemistry and other essential ancillary data are sometimes split in several publications and/or part of the data remains unpublished. Additionally, variables of the carbonate system are reported on different $\mathrm{pH}$ scales (N.B.S./N.I.S.T., total, free, or sea water; Dickson, 2010), using different sets of equilibrium constants, which make data comparison difficult. The main goals of the EPOCA/EUR-OCEANS data rescue and transformation project are to (1) obtain data from papers already published and archive them as supplementary data sets at PANGAEA - the Publishing Network for Geoscientific \& Environmental Data, giving full credit to the original authors, (2) compute a consistent set of carbonate chemistry variables, and (3) safeguard the consolidated data set at PANGAEA, thus ensuring open access to this unique data.

Data on seawater carbonate chemistry and biological processes from experiments and observations from the world ocean were compiled. The project was initiated by EUROCEANS in January 2008, with the aim to gather data on the effects of ocean acidification on marine organisms and EPOCA took over in August 2008. This is an on-going effort that will be continued at least during the lifetime of EPOCA (until May 2012).

\section{Data provenance and collection of relevant papers}

A literature search was conducted and data from selected papers were obtained directly from the authors as numerical
Table 1. Carbonate System Computation (CSC) flags describing which pair of variables (in addition to salinity and temperature) were used to compute the carbonate system variables listed in Table 2 .

\begin{tabular}{|c|c|c|}
\hline CSC flag & Software & Input variables \\
\hline 1 & seacarb & $\mathrm{pH}_{\mathrm{T}}$ and $\mathrm{CO}_{2}$ \\
\hline 2 & seacarb & $\mathrm{CO}_{2}$ and $\mathrm{HCO}_{3}$ \\
\hline 3 & seacarb & $\mathrm{CO}_{2}$ and $\mathrm{CO}_{3}$ \\
\hline 4 & seacarb & $\mathrm{CO}_{2}$ and $A_{\mathrm{T}}$ \\
\hline 5 & seacarb & $\mathrm{CO}_{2}$ and $C_{\mathrm{T}}$ \\
\hline 6 & seacarb & $\mathrm{pH}_{\mathrm{T}}$ and $\mathrm{HCO}_{3}$ \\
\hline 7 & seacarb & $\mathrm{pH}_{\mathrm{T}}$ and $\mathrm{CO}_{3}$ \\
\hline 8 & seacarb & $\mathrm{pH}_{\mathrm{T}}$ and $A_{\mathrm{T}}$ \\
\hline 9 & seacarb & $\mathrm{pH}_{\mathrm{T}}$ and $C_{\mathrm{T}}$ \\
\hline 10 & seacarb & $\mathrm{HCO}_{3}$ and $\mathrm{CO}_{3}$ \\
\hline 11 & seacarb & $\mathrm{HCO}_{3}$ and $A_{\mathrm{T}}$ \\
\hline 12 & seacarb & $\mathrm{HCO}_{3}$ and $C_{\mathrm{T}}$ \\
\hline 13 & seacarb & $\mathrm{CO}_{3}$ and $A_{\mathrm{T}}$ \\
\hline 14 & seacarb & $\mathrm{CO}_{3}$ and $C_{\mathrm{T}}$ \\
\hline 15 & seacarb & $A_{\mathrm{T}}$ and $C_{\mathrm{T}}$ \\
\hline 21 & seacarb & $p \mathrm{CO}_{2}$ and $\mathrm{pH}_{\mathrm{T}}$ \\
\hline 22 & seacarb & $p \mathrm{CO}_{2}$ and $\mathrm{HCO}_{3}$ \\
\hline 23 & seacarb & $p \mathrm{CO}_{2}$ and $\mathrm{CO}_{3}$ \\
\hline 24 & seacarb & $p \mathrm{CO}_{2}$ and $A_{\mathrm{T}}$ \\
\hline 25 & seacarb & $p \mathrm{CO}_{2}$ and $C_{\mathrm{T}}$ \\
\hline \multirow[t]{2}{*}{26} & Step 1. CO2SYS & $\mathrm{pH}$ (other scale) and $A_{\mathrm{T}}$ \\
\hline & Step 2. seacarb & $A_{\mathrm{T}}$ and $C_{\mathrm{T}}$ (obtained with CO2SYS) \\
\hline \multirow[t]{2}{*}{27} & Step 1. CO2SYS & $\mathrm{pH}$ (other scale) and $C_{\mathrm{T}}$ \\
\hline & Step 2. seacarb & $A_{\mathrm{T}}$ and $C_{\mathrm{T}}$ (obtained with CO2SYS) \\
\hline \multirow[t]{2}{*}{28} & Step 1. CO2SYS & $\mathrm{pH}$ (other scale) and $f \mathrm{CO}_{2}$ \\
\hline & Step 2. seacarb & $A_{\mathrm{T}}$ and $C_{\mathrm{T}}$ (obtained with CO2SYS) \\
\hline \multirow[t]{2}{*}{29} & Step 1. CO2SYS & $\mathrm{pH}$ (other scale) and $p \mathrm{CO}_{2}$ \\
\hline & Step 2. seacarb & $A_{\mathrm{T}}$ and $C_{\mathrm{T}}$ (obtained with CO2SYS) \\
\hline
\end{tabular}

files or, alternatively, data were extracted from tables in the original paper. Papers were selected with the following criteria: (1) only data measured under $p \mathrm{CO}_{2}$ or $\mathrm{pH}$ levels that are relevant to past or for future scenarios (i.e. $p \mathrm{CO}_{2}$ values ranging from about 100 to $1700 \mu \mathrm{atm}$ and $\mathrm{pH}_{\mathrm{T}}$ values of 7.5 to 8.5 ) were considered. (2) salinity and temperature, at least two variables of the carbonate system were needed (Table 1). Once papers were identified, requests for data were sent to the corresponding authors. When there was no reply after three months, a reminder was sent, and another reminder was sent if there was still no reply after 6 months. If after 9 months from the first request there was still no reply, the data were considered unavailable.

A total of 185 papers were identified in the literature search but 50 did not meet the criteria mentioned above. Of the remaining 136 papers, the authors provided data from 100 papers, 23 did not reply, and 13 were unfortunately unable to locate the data (Fig. 1). In some cases, papers shared data from multidisciplinary studies, for example six papers included data from the 2001 Pelagic Ecosystem $\mathrm{CO}_{2}$ Enrichment Study (PeECE I). In such cases, data from the related papers were combined into a single data set, which explains why out of 100 papers, there are 81 data sets archived. 


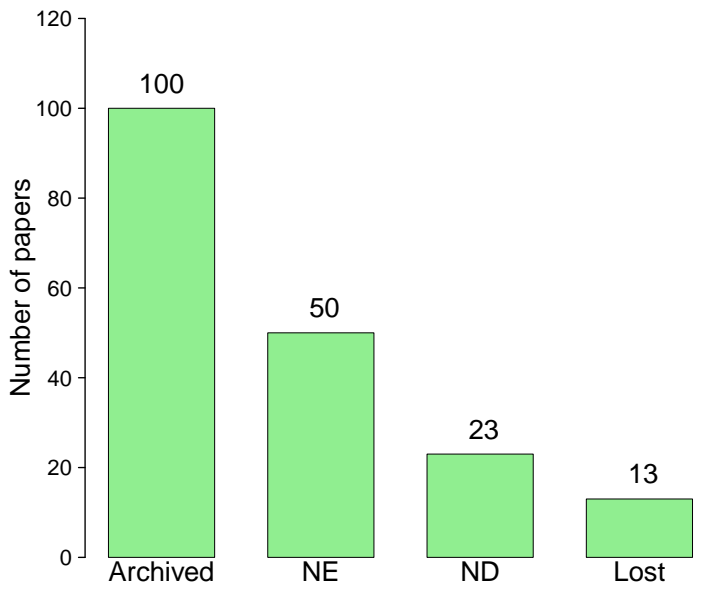

Figure 1. Summary of the data compilation. The number of papers successfully included in the database (archived) versus those in which only one carbonate system variable was reported (NE), papers for which data access was not possible (ND), or for which the data have been lost (Lost).

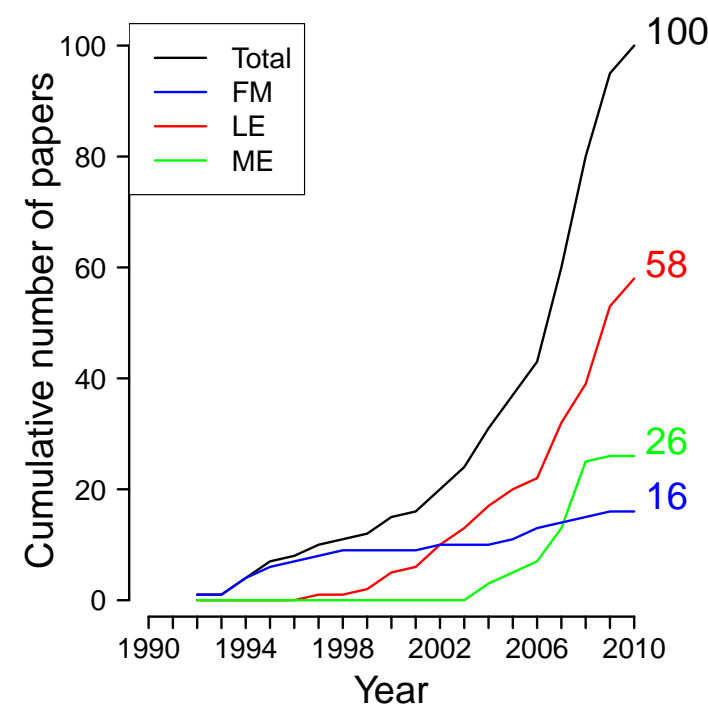

Figure 2. Total number of publications (Total) included in the database, including field measurements (FM), as well as laboratory (LE) and mesocosm experiments (ME).

The data collected were from laboratory and mesocosm experiments, as well as field measurements (Fig. 2). Laboratory experiments included the seawater $p \mathrm{CO}_{2}$ or $\mathrm{pH}$ perturbation experiments conducted in different laboratories. It is the category, which comprises most papers (58). Mesocosm experiments (26 papers) included three large PeECE projects that were carried out near Bergen (Norway) in 2001, 2003 and 2005, together comprising 23 publications. The database also includes data sets from three publications on mesocosm experiments performed in Hawaii and South Korea. The category "field measurements" comprises all data sets reporting natural seawater carbonate chemistry measurements and relevant biological and biogeochemical processes (16 publications).

\section{Geographical coverage}

The geographical coverage of the studied organisms from the EPOCA/EUR-OCEANS data rescue and transformation project on the impacts of ocean acidification data includes all the world oceans except the Southern Ocean. The investigated organisms were living or collected in these locations, including the phytoplankton and bacteria cultured in laboratories after isolation for several years. In recent years there has been some discussion as to whether phytoplankton and bacteria strains collected several years ago, hundreds of generations later may not be genetically identical to the natural populations.

The areas investigated are divided into two groups. The first group (shown in black in Fig. 3) includes studies of organisms in their natural habitat, organisms that were collected shortly before the experiment and corals that have been maintained in aquaria for several years but are genetically identical to their field counterparts. The second group (shown in red in Fig. 3) comprises phytoplankton and bacteria species that have been collected several years ago but they have gone through hundreds of generations.

Most of the natural community studies were conducted in the Northeast Atlantic (34\%), including two studies above $78^{\circ} \mathrm{N}$. About $10 \%$ of the studies were performed in the central Western Pacific, 9\%, Northwest Pacific and 8\% in the central Eastern Pacific. Even though the Mediterranean and Black Sea area represents a relatively small surface area of the world ocean $(0.8 \%)$ it has contributed to a relatively large percentage of the papers archived in the present data compilation (8\%). Studies from the Western Indian Ocean area make up about $5 \%$ of the publications comprised in the database. Studies from the Central Western Atlantic and Eastern Indian Ocean only represent 5\% and 3\% of the papers.

The largest amount of studies was performed with phytoplankton and bacteria species collected from the Northeast Atlantic ( $11 \%$ of the papers). Only $2 \%$ of the papers on ocean acidification have been written about studies conducted on organisms collected from the Southeast Atlantic Ocean. The Mediterranean and Black sea area and the central Western Pacific area both represent $1 \%$ of the papers (Fig. 3).

In general the Southern Hemisphere and higher latitudes are relatively poorly represented in the EPOCA/EUROCEANS data rescue and transformation compilation. The geographical coverage of ocean acidification impact studies is similar to that of coastal biogeochemistry studies (Gattuso et al., 2005). Moreover, there is no direct relationship with the research intensity and the systems vulnerability. Model results suggest that the surface waters of the polar oceans will 


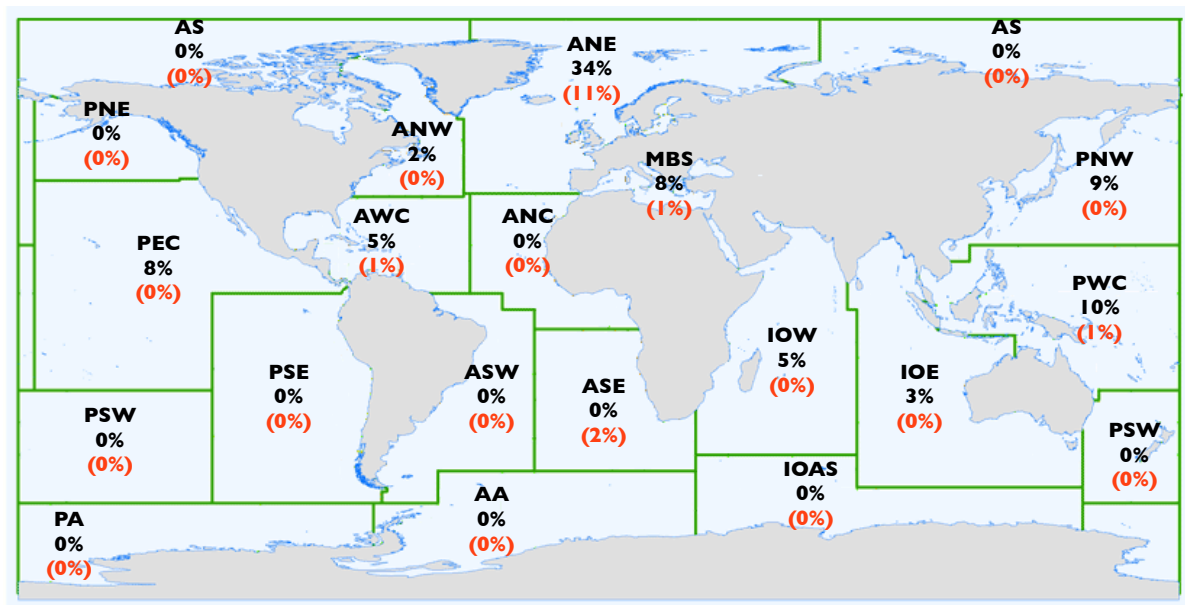

Figure 3. Regional distribution of the organisms and communities investigated, broken down following the Food and Agriculture Organization of the United Nations (FAO) major fishing areas. AS, Arctic Sea; ANW, Atlantic, Northwest; ANE, Atlantic, Northeast; AWC, Atlantic, Western Central; ANC, Atlantic, Eastern Central; MBS, Mediterranean and Black Sea; ASW, Atlantic, Southwest; ASE, Atlantic, Southeast; AA, Atlantic, Antarctic; IOW, Indian Ocean, Western; IOE, Indian Ocean, Eastern; IOAS, Indian Ocean, Antarctic and Southern; PNW, Pacific, Northwest; PNE, Pacific, Northeast; PWC, Pacific, Western Central; PEC, Pacific, Eastern Central; PSW, Pacific, Southwest; PSE, Pacific, Southeast; PA, Pacific, Antarctic. Areas of natural communities, organisms that were collected in these areas shortly before the experiment and coral sampling sites are shown in black while organisms that have gone through many generations are shown in red.

Table 2. R package seacarb (Lavigne and Gattuso, 2010) computes the following carbonate system variables.

\begin{tabular}{ll}
\hline Short variable name & Long variable name and unit \\
\hline$S$ & Salinity \\
$T$ & Temperature $\left({ }^{\circ} \mathrm{C}\right)$ \\
$P$ & Pressure $($ bar $)$ \\
$\mathrm{pH}$ & $\mathrm{pH}_{\mathrm{T}}($ total scale)* \\
$\mathrm{CO}_{2}$ & Carbon dioxide concentration $\left(\mathrm{mol} \mathrm{kg}^{-1}\right)$ \\
$p \mathrm{CO}_{2}$ & Carbon dioxide partial pressure $(\mu \mathrm{atm})$ \\
$\mathrm{CO}_{2}$ & Carbon dioxide fugacity $(\mu \mathrm{atm})$ \\
$\mathrm{HCO}_{3}$ & Bicarbonate concentration $\left(\mathrm{mol} \mathrm{kg} \mathrm{kg}^{-1}\right)$ \\
$\mathrm{CO}_{3}$ & Carbonate ion concentration $\left(\mathrm{mol} \mathrm{kg}^{-1}\right)$ \\
$C_{\mathrm{T}}$ & Dissolved inorganic carbon concentration $\left(\mathrm{mol} \mathrm{kg}^{-1}\right)$ \\
$A_{\mathrm{T}}$ & Total alkalinity (mol kg \\
OmegaAragonite & Aragonite saturation state \\
OmegaCalcite & Calcite saturation state \\
\hline
\end{tabular}

* The definition of $\mathrm{pH}$ is implicitly based on a concentration unit for hydrogen ion, although the $\mathrm{pH}$ value itself has the dimension 1 . The concentration unit for hydrogen ion used here in $\mathrm{mol} \mathrm{kg}^{-1}$.

be the first to become undersaturated with respect to aragonite. This may already occur in 2050 in the Southern Ocean (Orr et al., 2005; McNeil and Matear, 2007) and as early as 2016 in the Arctic Ocean (Steinacher et al., 2009). However there are very few studies performed in these areas. This raises great concern if research efforts are well distributed with respect to the vulnerability of ecosystems.

\section{Harmonising the carbonate chemistry data}

In order to harmonise data the $\mathrm{R}$ package seacarb (Lavigne and Gattuso, 2010) was used to compute a complete and consistent set of carbonate system variables (Table 2). Original data of temperature, salinity, pressure, any pair of carbonate system variables (Table 1) and, if available, the concentrations of silicate and phosphate were used. When the original values were expressed in $\mathrm{moll}^{-1}$, they were converted to mol $\mathrm{kg}^{-1}$ by dividing by density calculated from salinity and temperature as indicated in Dickson et al. (2007). pH, can be measured using different scales, these include the total hydrogen ion, seawater, free and N.B.S./N.I.S.T. (National Bureau of Standards, currently National Institute of Standards and Technology) scales. When $\mathrm{pH}$ was reported on a scale other the than total scale, the dissolved inorganic carbon $\left(C_{\mathrm{T}}\right)$ and total alkalinity $\left(A_{\mathrm{T}}\right)$ were first calculated with CO2SYS (Lewis and Wallace, 1998) and subsequently used in seacarb (which does not handle the N.B.S. scale) to estimate $\mathrm{pH}$ on the total scale as well as the other carbonate system variables. The pair of carbonate system variables that was used for computations in seacarb and was CO2SYS is identified by a flag (Table 1). For the sake of traceability, that flag was archived in the data sets as a separate variable called "Carbonate System Computation flag" or "CSC flag". The dissociation constants used for calculations with seacarb are from Lueker et al. (2000) for carbonic acid $\left(K_{1}\right.$ and $\left.K_{2}\right)$, Perez and Fraga (1987) for hydrogen fluoride and those recommended by Dickson et al. (2007) for all other constants. 

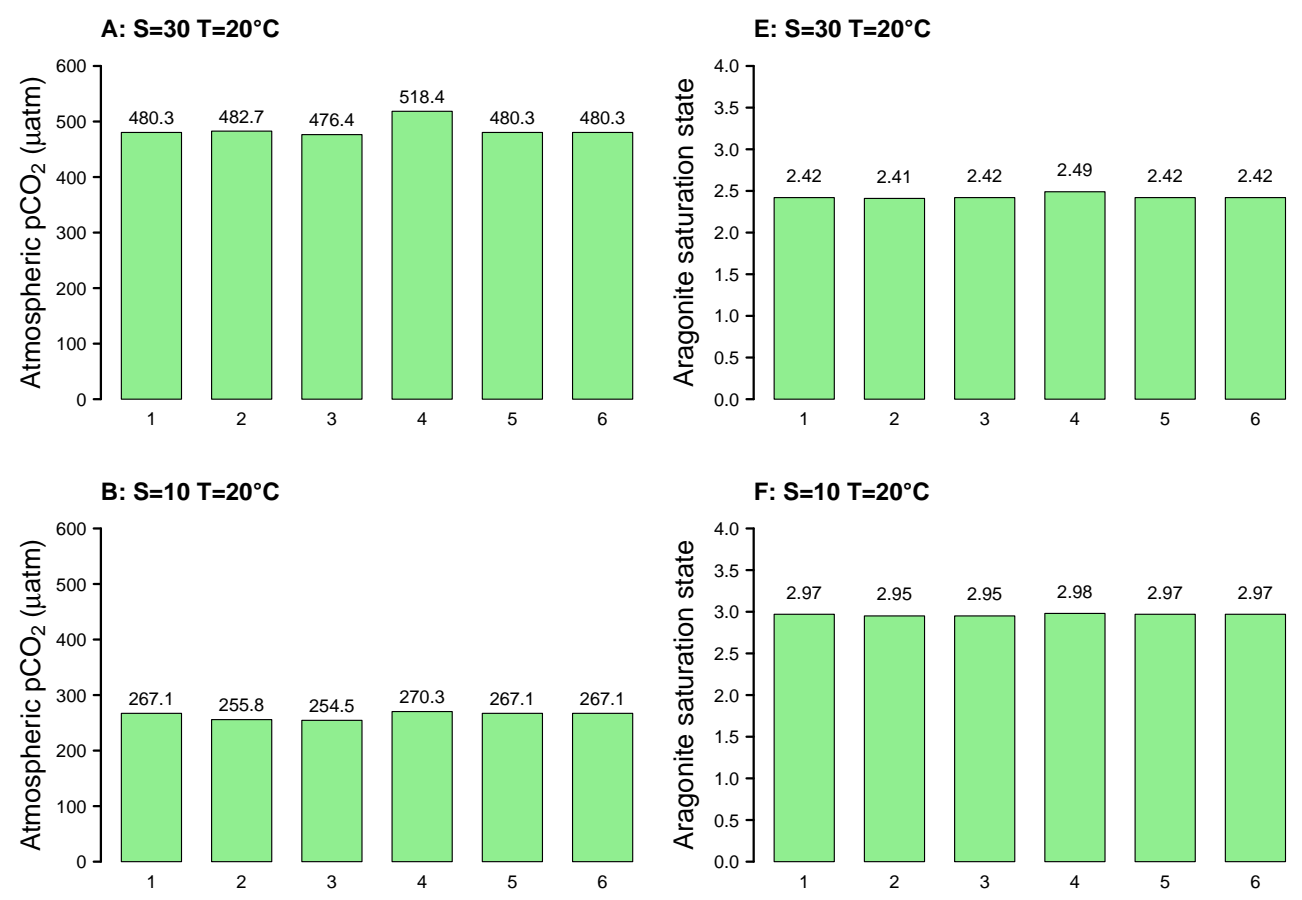

$\mathrm{C}: \mathrm{S}=30 \mathrm{~T}=0^{\circ} \mathrm{C}$

G: $\mathrm{S}=30 \mathrm{~T}=0^{\circ} \mathrm{C}$
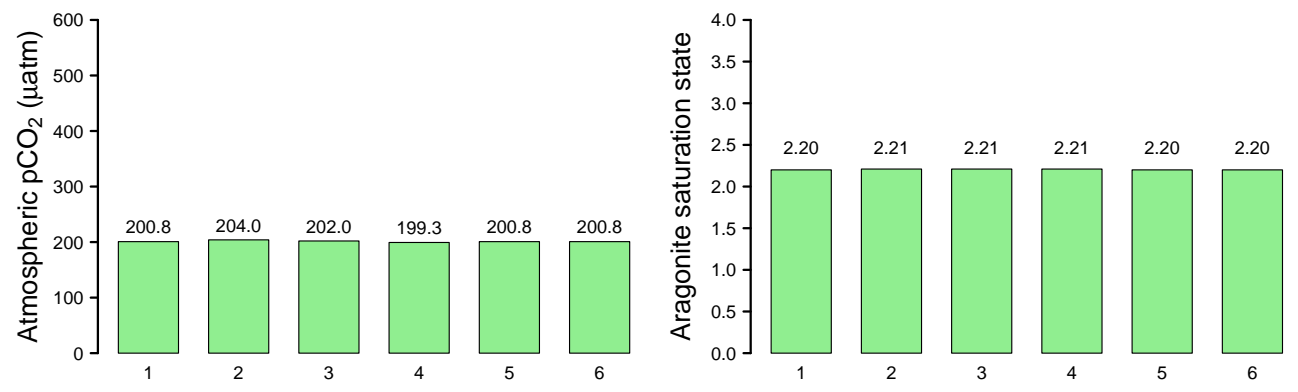

D: $\mathrm{S}=10 \mathrm{~T}=0^{\circ} \mathrm{C}$

\section{$\mathrm{H}: \mathrm{S}=10 \mathrm{~T}=0^{\circ} \mathrm{C}$}
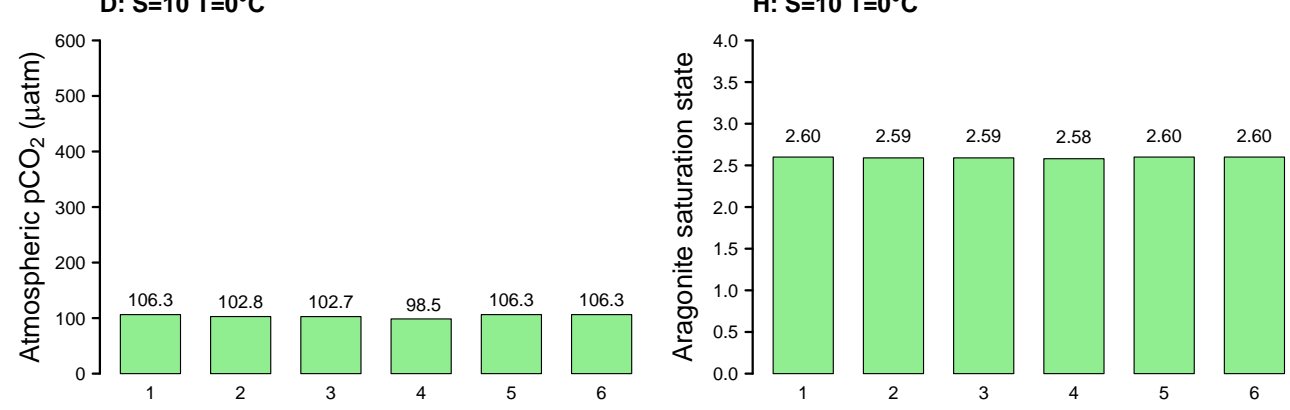

Figure 4. $p \mathrm{CO}_{2}$ and $\Omega_{a}$ for four combinations of salinity $(S)$ and temperature $(T)$ and using different formulations for the dissociation constants of carbonic acid, hydrogen fluoride and hydrogen sulphate (see Table 3). Calculations were performed with seacarb using constant values of total alkalinity $\left(2300 \times 10^{-6} \mathrm{~mol} \mathrm{~kg}^{-1}\right)$ and total carbon $\left(2100 \times 10^{-6} \mathrm{~mol} \mathrm{~kg}^{-1}\right)$ and with concentrations of total phosphate and total silicate of $0 \times 10^{-6} \mathrm{~mol} \mathrm{~kg}^{-1}$.

The dissociation constants are valid for restricted range of salinity $(S)$ and temperature $(T)$. Dickson et al. (2007) recommend the formulations of Lueker et al. (2000) for carbonic acid $\left(K_{1}\right.$ and $\left.K_{2} ; S=19-43, T=2-35^{\circ} \mathrm{C}\right)$, Perez and
Fraga (1987) for hydrogen fluoride $\left(K_{f} ; S=10-40, T=9-\right.$ $\left.33^{\circ} \mathrm{C}\right)$ and Dickson $(1990)$ for hydrogen sulphate $\left(K_{s} ; S=5-\right.$ $\left.45, T=0-45^{\circ} \mathrm{C}\right)$. Although most of the data sets compiled have salinity and temperature values within the ranges for 
Table 3. Formulations used for the dissociation constants of carbonic acid $\left(K_{1}\right.$ and $\left.K_{2}\right)$, hydrogen fluoride $\left(K_{f}\right)$ and hydrogen sulfate $\left(K_{s}\right)$ in the 6 cases shown in Fig. 4. The ranges of salinity and temperature for which these formulations are valid are given in brackets.

\begin{tabular}{clll}
\hline ID & $K_{1}$ and $K_{2}$ & $K_{f}$ & $K_{S}$ \\
\hline 1 & Lueker et al. $(2000)$ & Perez and Fraga $(1987)$ & Dickson $(1990)$ \\
& {$[S=19-43 ; T=2-35]$} & {$[S=10-40 ; T=9-33]$} & {$[S=5-45 ; T=0-45]$} \\
2 & Millero et al. $(2006)$ & Perez and Fraga $(1987)$ & Dickson $(1990)$ \\
& {$[S=0.1-50 ; T=1-50]$} & {$[S=10-40 ; T=9-33]$} & {$[S=5-45 ; T=0-45]$} \\
3 & Millero $(2010)$ & Perez and Fraga $(1987)$ & Dickson $(1990)$ \\
& {$[S=1-50 ; T=0-50]$} & {$[S=10-40 ; T=9-33]$} & {$[S=5-45 ; T=0-45]$} \\
4 & Roy et al. $(1993)$ & Perez and Fraga $(1987)$ & Dickson $(1990)$ \\
& {$[S=0-45 ; T=0-45]$} & {$[S=10-40 ; T=9-33]$} & {$[S=5-45 ; T=0-45]$} \\
5 & Lueker et al. $(2000)$ & Dickson and Riley & Dickson $(1990)$ \\
& {$[S=19-43 ; T=2-35]$} & $(1979) \quad[S=0-45 ; T=0-45]$ & {$[S=5-45 ; T=0-45]$} \\
& & & \\
6 & Lueker et al. $(2000)$ & Perez and Fraga $(1987)$ & Khoo et al. $(1977)$ \\
& {$[S=19-43 ; T=2-35]$} & {$[S=10-40 ; T=9-33]$} & {$[S=20-45 ; T=5-40]$} \\
\hline
\end{tabular}

which these formulations are valid, a few have salinity and temperature values outside these ranges. Among the 100 papers, $95 \%$ are within the ranges of salinity and temperature above. Two data sets have salinity values ranging between 5 and 19, two have temperature values ranging between 2 and $5^{\circ} \mathrm{C}$, and one has temperature values ranging between 5 and $9{ }^{\circ} \mathrm{C}$.

The difference in seawater carbonate chemistry obtained with various formulations was investigated using a $C_{T}$ of $2100 \times 10^{-6} \mathrm{~mol} \mathrm{~kg}^{-1}$ and $A_{\mathrm{T}}$ of $2300 \times 10^{-6} \mathrm{~mol} \mathrm{~kg}^{-1}$, and values for salinity and temperature inside and outside the ranges above ( $S$ of 10 and $30 ; T$ of 0 and $20^{\circ} \mathrm{C}$ ). These four conditions were used to calculate the seawater carbonate chemistry with seacarb using the formulations recommended by Dickson et al. (2007) as well as formulations valid for ranges of $S$ and $T$ that include the lower values of $S=10$ and $T=0{ }^{\circ} \mathrm{C}$. The later formulations are those of Roy et al. (1993), Millero et al. (2006) and Millero et al. (2010) for carbonic acid, Dickson and Riley (1979) for hydrogen fluoride and Khoo et al. (1977) for hydrogen sulfate (see Table 3 for the actual ranges of $S$ and $T$ for which these formulations are valid). In general, the values of $p \mathrm{CO}_{2}$ and aragonite saturation state $\left(\Omega_{\mathrm{a}}\right)$ do not change significantly as a function of the different formulations used (Fig. 4). The largest difference was found at the higher levels of salinity and temperature ( $S=30$ and $T=20^{\circ} \mathrm{C}$ ) with $K_{1}$ and $K_{2}$ from Roy et al. (1993) with which $p \mathrm{CO}_{2}$ was 35 to $42 \mu$ atm higher than with the others formulations. The other significant difference was found for $S=10$ and $T=0{ }^{\circ} \mathrm{C}$ where $p \mathrm{CO}_{2}$ was lower by $8 \mu$ atm with the formulation of Roy et al. (1993) than with the other ones. In conclusion, the various formulations, except that of Roy et al. (1993) for $K_{1}$ and $K_{2}$, result in differences in parameters of the carbonate chemistry that are small in the context of perturbation experiments, even when salinity and temperature are outside the range of applicability. Therefore, the formulations of Lueker et al. (2000) for carbonic acid, Perez

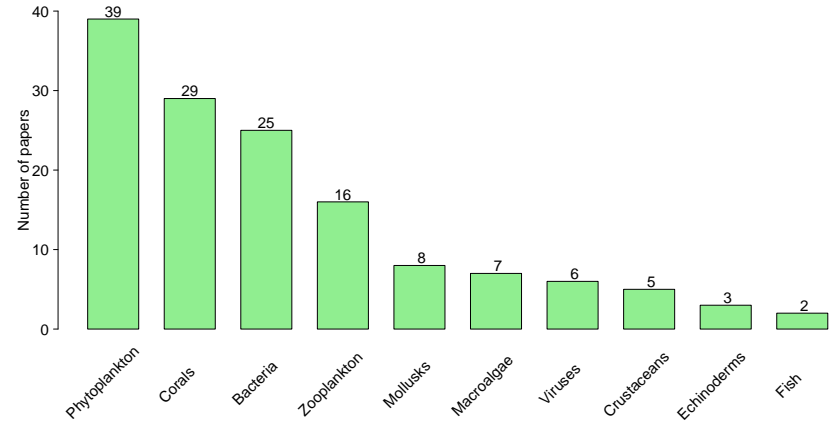

Figure 5. Taxonomic coverage of the papers included in the database.

and Fraga (1987) for hydrogen fluoride and Dickson (1990) for hydrogen sulfate were used for all data sets collected in the EPOCA/EUR-OCEANS data compilation.

Each value was archived at PANGAEA (http://www. pangaea.de) with its corresponding metadata, including citation, sampling and analysis methods, variable description and units. Once the data were imported in the database, the data providers were requested to quality control their data. All EPOCA/EUR-OCEANS data rescue and transformation project data sets are publicly available.

\section{Taxonomic coverage}

Studies were mostly carried out on phytoplankton (39 papers published, including 33 on the coccolithophore Emiliania huxleyi), scleractinian corals (29 papers), bacteria (25) and zooplankton (16). Few studies were performed on molluscs, macroalgae, viruses, crustaceans, fish and echinoderms (Fig. 5). 


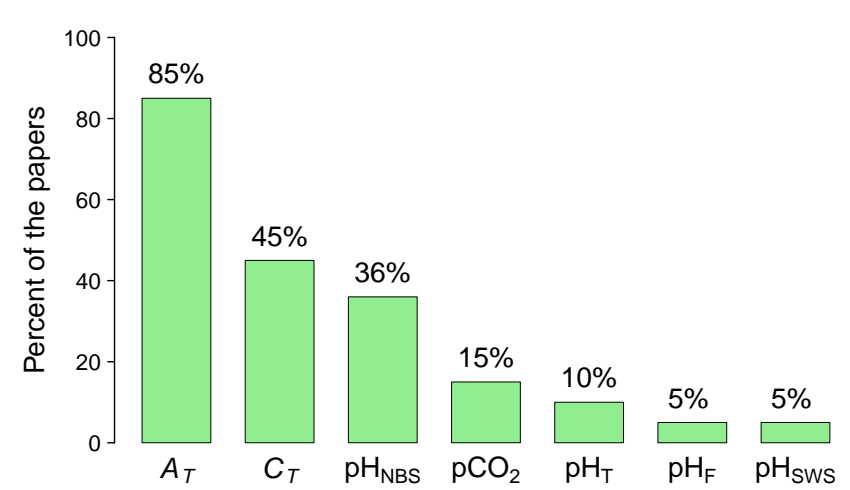

Figure 6. Variables of the seawater carbonate system reported in the papers.

\section{Measured parameters}

All data sets include all of the carbonate system variables (Table 2), but the original measurements were made on different sets of variables. The carbonate system variable most measured is total alkalinity $\left(A_{\mathrm{T}}\right)$ that is reported in about $85 \%$ of the papers (Fig. 6). The second most measured variable is dissolved inorganic carbon $\left(C_{\mathrm{T}} ; 45 \%\right)$. In $36 \%$ of the papers, $\mathrm{pH}$ is reported on the N.B.S./N.I.S.T. scale. Out of all publications, $15 \%$ included $p \mathrm{CO}_{2}$ as one of the original variables, and 5\% had measured $\mathrm{pH}$ on the free and seawater scale (Fig. 6). The relatively large number of papers that reported $\mathrm{pH}$ on the N.B.S./N.I.S.T. scale could be surprising. However, it is only recently that the ocean acidification community has been made aware that this scale should not be used to measure the difference in the concentration constants of the calculation of the hydrogen ion (Dickson, 1993). Only $10 \%$ of the papers included in the database reported $\mathrm{pH}$ on the total scale (Fig. 6), the scale that is currently recommended (Dickson et al., 2007; Dickson, 2010) for seawater.

In physiological studies the carbonate system is typically calculated from measurement of $\mathrm{pH}_{\mathrm{NBS}}$ (calibrated in dilute N.B.S./N.I.S.T. buffers) and a single point titration of alkalinity $\left(A_{\mathrm{T}}\right)$. This approach has been widespread appeal because it is simple, inexpensive, and requires very low sample volumes. However, its continued application ignores advances in analytical and theoretical oceanic $\mathrm{CO}_{2}$ chemistry that suggest fundamental flaws in the assumption $\mathrm{pH}_{\mathrm{NBS}}=-\log \left[\mathrm{H}^{+}\right]$ as a consequence of the high ionic strength of seawater and liquid residual junction errors in the electrode (Crawford and Harrison, 1997).

The biological process most measured was calcification ( $31 \%$ of the papers; Fig. 7 ). Other variables that can potentially be affected by ocean acidification and are often measured include primary production $(13 \%)$, growth rate $(11 \%)$, respiration $(8 \%)$, photosynthesis $(8 \%)$, survival $(4 \%)$ and reproductive processes $(3 \%)$. Primary production here comprises several production variables such as net production rate, community production and net carbon production as

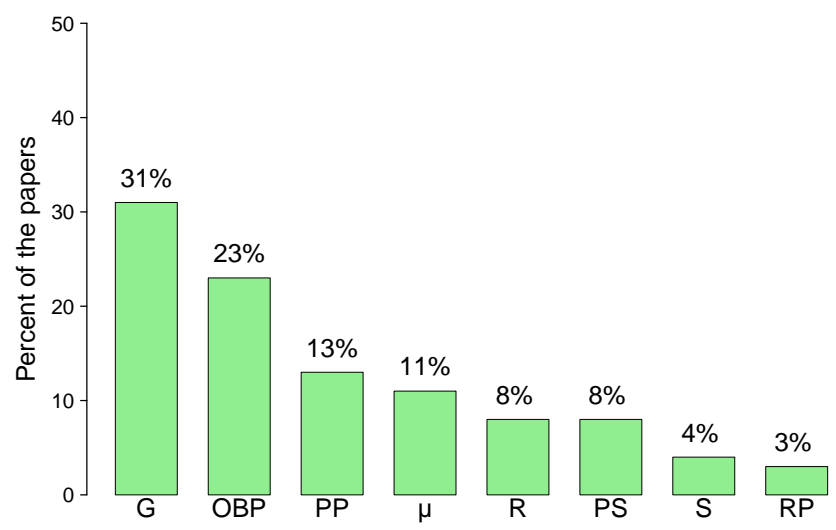

Figure 7. Biological processes reported in the papers: G, calcification rate; OBP, other biological variables; PP, primary production; $\mu$, growth rate; R, respiration; PS, photosynthesis; RP, reproductive processes; and $\mathrm{S}$, survival.

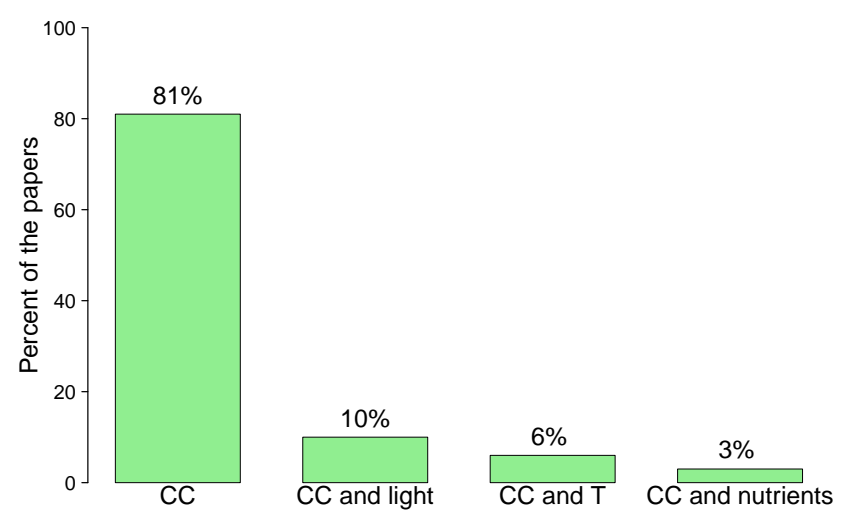

Figure 8. Percent of the papers that have manipulated the carbonate chemistry alone and those that have manipulated the carbonate chemistry as well as another variable. CC, carbonate chemistry; T, temperature.

well as the production of particulate organic carbon, inorganic carbon, nitrogen and phosphorus. The database also comprises $23 \%$ other biological variables that were included in single papers. This category comprises variables such as shell length, width and linear extension of molluscs, bleaching, invasion, orientation, different blood cell concentration, concentration in the tissues of organisms, rate of nitrogen fixation.

About $81 \%$ of the compiled papers have only manipulated the carbonate chemistry (Fig. 8). Few publications have reported the combined effects of changed carbonate chemistry and light $(10 \%)$. Some studies have also manipulated temperature (6\% of papers) and nutrients (3\%) together with carbonate chemistry. 


\section{Data access}

The EPOCA/EUR-OCEANS data rescue and transformation on the impact of ocean acidification is available freely and with no restrictions in the PANGAEA data library at http: //doi.pangaea.de/10.1594/PANGAEA.735138.

\section{Recommendations}

During the compilation of the EPOCA/EUR-OCEANS data rescue and transformation several obstacles were met. While conducting ocean acidification experiments at least two carbonate system parameters should be measured along with salinity and, temperature. Furthermore recent studies have shown that synergistic stressors such as ocean acidification and hypoxia narrow thermal windows according to speciesspecific sensitivities, modulating bio- geographies, coexistence ranges, and other interactions (Pörtner and Farrell, 2008). The oxygen concentration is therefore an interesting parameter to report alongside temperature and carbonate chemistry. To streamline future archiving, it is recommended that all data and metadata should be provided with a high level of detail (including the scale on which $\mathrm{pH}$ measurements were made) and that seawater carbonate chemistry should be reported in mole per $\mathrm{kg}$ of seawater instead of mole per liter of seawater. Other technical recommendations are provided by Pesant et al. (2010).

Some geographical areas have received much more attention than others. It seems essential that data on the response to ocean acidification be gathered in high latitude areas as well as in areas that exhibit naturally low $\mathrm{pH}$, such as the North and Eastern Pacific and upwelling areas. Also more studies are necessary to investigate the combined effects of changes in the carbonate chemistry and changes of other variables such as temperature, irradiance, concentration of nutrients. Some taxonomic groups are rather poorly studied including species of commercial interest such as fish, crustaceans and echinoderms.

Acknowledgements. We thank all authors who have graciously provided data. Andrew Dickson has provided advice on the characteristics of the carbonate chemistry at low seawater temperature. $\mathrm{N}$. Taalba contributed to a preliminary data compilation. This work is a contribution to the European Project on Ocean Acidification (EPOCA; which received funding from the European Community's Seventh Framework Programme (FP7/2007-2013) under grant agreement no. 211384) and to the European Network of Excellence for Ocean Ecosystems Analysis (EUR-OCEANS).

Edited by: F. Schmitt

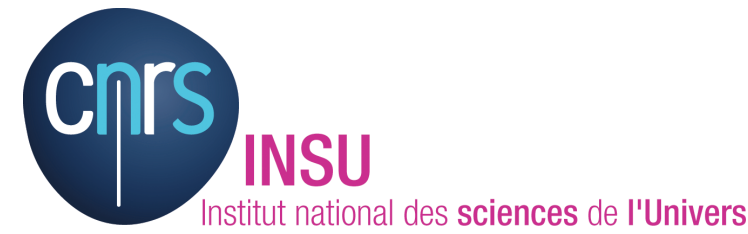

The publication of this article is financed by CNRS-INSU.

\section{References}

Crawford, D. W. and Harrison, P. J.: Direct measurement of $\mathrm{pCO}_{2}$ in cultures of marine phytoplankton: how good is the estimate from $\mathrm{pH}_{\mathrm{NBS}}$ and single point titration of alkalinity?, Mar. Ecol. Prog. Ser., 158, 61-74, 1997.

Delille, B., Harlay, J., Zondervan, I., Jacquet, S., Chou, L., Wollast, R., Bellerby, R. G. J., Frankignoulle, M., Borges, A. V., Riebesell, U. and Gattuso, J.-P.: Response of primary production and calcification to changes of $\mathrm{pCO}_{2}$ during experimental blooms of the coccolithophorid Emiliania huxleyi, Global Biogeochem. Cy., 19, GB2023, doi:10.129/2004GB002318, 2005.

Dickson A. G.: Standard potential of the reaction: $\mathrm{AgCI}(\mathrm{s})+$ $1 / 2 \mathrm{H}_{2}(\mathrm{~g})=\mathrm{Ag}(\mathrm{s})+\mathrm{HCI}(\mathrm{aq})$, and the standard acidity constant of the ion $\mathrm{HSO}_{4}^{-}$in synthetic sea water from 273.15 to 318.15 K., J. Chem. Thermodyn., 22, 113-127, 1990.

Dickson, A. G.: The measurement of sea water $\mathrm{pH}, \mathrm{Mar}$ Chem., 44, 131-142, 1993.

Dickson, A. G.: The carbon dioxide system in seawater: equilibrium chemistry and measurements, in: Guide to best practices for ocean acidification research and data reporting, edited by: Riebesell, U., Fabry, V. J., Hansson, L., and Gattuso, J.-P., Publications Office of the European Union, Luxembourg, 17-40, 2010.

Dickson, A. G. and Riley, J. P.: The estimation of acid dissociation constants in seawater media from potentiometric titrations with strong base. I. The ionic product of water, Mar. Chem., 7, 89-99, 1979.

Dickson, A. G., Sabine, C. L., and Christian J. R.: Guide to best practices for ocean $\mathrm{CO}_{2}$ measurements, PICES Special Publication, 3, 1-191, 2007.

Gattuso, J.-P., Allemand, D., and Frankignoulle, M.: Photosynthesis and calcification at cellular, organismal and community levels in coral reefs: a review on interactions and control by carbonate chemistry, Am. Zool., 39, 160-183, 1999.

Gattuso, J.-P., Dawson, N., Duarte, C. M., and Middelburg, J. J.: Patterns of publication effort in coastal biogeochemistry: a bibliometric survey (1971-2003), Mar. Ecol. Prog. Ser., 294, 9-22, 2005.

Khoo, H. K., Ramette, R. W., Culberson, C. H., and Bates, R. G.: Determination of hydrogen ion concentration in seawater from 4 to $40^{\circ} \mathrm{C}$ : standard potentials at salinities from 20 to 45 , Anal. Chem., 22, 29-34, 1977.

Lavigne, H. and Gattuso, J.-P.: seacarb: seawater carbonate chemistry with $\mathrm{R}, \mathrm{R}$ package version 2.3 .3 , http://CRAN.R-project. org/package=seacarb (last access: 29 May 2010), 2010.

Le Quéré, C., Raupach, M. R., Canadell, J. G., Marland, G., Bopp, L., Ciais, P., Conway, T. J., Doney, S. C., Feely, R., Foster, P., Friedlingstein, P., Gurney, K., Houghton, R. A., House, J. I., Huntingford, C., Levy, P. E., Lomas, M. R., Majkut, J., Metzl, N., Ometto, J. P., Peters, G. P., Prentice, I. C., Randerson, J. T., 
Running, S. W., Sarmiento, J. L., Schuster, U., Sitch, S., Takahashi, T., Viovy, N., van der Werf, G. R., and Woodward, F. I.: Trends in the sources and sinks of carbon dioxide, Nat. Geosci., 2, 831-836, 2009.

Lewis, E. and Wallace, D. W. R.: Program Developed for $\mathrm{CO}_{2}$ System Calculations, ORNL/CDIAC-105. Carbon Dioxide Information Analysis Center, Oak Ridge National Laboratory, US Department of Energy, Oak Ridge, Tennessee, 1998.

Mc Neil, B. I. and Matear, R. J.: Climate change feedbacks on future oceanic acidification, Tellus B, 59, 191-198, 2007.

Lueker, T. J., Dickson, A. G., and Keeling, C. D.: Ocean $\mathrm{pCO}_{2}$ calculated from dissolved inorganic carbon, alkalinity, and equations for $K_{1}$ and $K_{2}$ : validation based on laboratory measurements of $\mathrm{CO}_{2}$ in gas and seawater at equilibrium, Mar. Chem., $70,105-119,2000$.

Millero, F. J.: Thermodynamics of the carbon dioxide system in the oceans, Geochim. Cosmochim. Ac., 59, 661-677, 1995.

Millero, F. J.: Carbonate constant for estuarine waters, Mar. Freshwater Res., 61, 139-142, 2010.

Orr, J. C., Fabry, V. J., Aumont, O., Bopp, L., Doney, S. C., Feely, R. A., Gnanadesikan, A., Gruber, N., Ishida, A., Joos, F., Key, R. M., Lindsay, K., Maier-Reimer, E., Matear, R., Monfray, P., Mouchet, A., Najjar, R. G., Plattner, G.-K., Rodgers, K. B., Sabine, C. L., Sarmiento, L. J., Schlitzer, R., Slater, R. D., Totterdell, I. J., Weirig, M.-F., Yamanaka, Y., and Yool, A.: Anthropogenic ocean acidification over the twenty-first century and its impact on calcifying organisms, Nature, 437, 681-686, 2005.
Perez, F. F. and Fraga, F.: Association constant of fluoride and hydrogen ions in seawater, Mar. Chem., 21, 161-168, 1987.

Pesant, S., Hook, L. A., Lowry, R., Moncoiffe, G., Nisumaa, A.-M., and Pfeil, B.: Safeguarding and sharing ocean acidification data, in: Guide to best practices for ocean acidification research and data reporting, edited by: Riebesell, U., Fabry, V. J., Hansson, L., and Gattuso, J.-P., Publications Office of the European Union, Luxembourg, 243-258, 2010.

Pörtner, H. O. and Farrell, A. P.: Physiology and climate change, Science, 322, 690-692, 2008.

Ridgwell, A. and Schmidt, D. A.: Past constraints on the vulnerability of marine calcifiers to massive carbon dioxide release, Nat. Geosci., 3, 196-200, 2010.

Riebesell, U., Zondervan, I., Rost, B., Tortell, P. D., and Morel, F. M. M.: Reduced calcification of marine plankton in response to increased atmospheric $\mathrm{CO}_{2}$, Nature, 407, 364-367, 2000.

Roy, R. N., Roy, L. N., Vogel, K. M., Porter-Moore, C., Pearson, T., Good, C. E., Millero, F. J., and Campbell, D. M.: The dissociation constants of carbonic acid in seawater at salinities 5 to 45 and temperatures 0 to $45^{\circ} \mathrm{C}$, Mar. Chem., 44, 249-267, 1993.

Steinacher, M., Joos, F., Frölicher, T. L., Plattner, G.-K., and Doney, S. C.: Imminent ocean acidification in the Arctic projected with the NCAR global coupled carbon cycle-climate model, Biogeosciences, 6, 515-533, doi:10.5194/bg-6-515-2009, 2009. 